\title{
Available phosphorus in diets with or without ractopamine for late finishing gilts ${ }^{1}$
}

\section{Priscila Furtado Campos ${ }^{2}$, Francisco Carlos de Oliveira Silva ${ }^{3}$, Aloízio Soares Ferreira ${ }^{4}$, Rita Flávia Miranda de Oliveira ${ }^{4}$, Juarez Lopes Donzele ${ }^{4}$, Celso José Girotto Júnior ${ }^{2}$, Cinthia Maria Carlos Pereira ${ }^{2}$, Alysson Saraiva ${ }^{5}$}

\author{
1 Financed by Fapemig. \\ 2 Programa de Pós-graduação em Zootecnia - UFV. \\ ${ }^{3}$ Epamig/Viçosa - MG \\ ${ }^{4} D Z O-U F V$ \\ ${ }^{5}$ DZO - UFVJM
}

ABSTRACT - With the objective to evaluate levels of available phosphorus (aP) in diets with or without ractopamine, 112 gilts with high genetic potential for meat deposition with initial weigh of $94.0 \pm 2.28 \mathrm{~kg}$ were allotted in a completely randomized block design, in a $4 \times 2$ factorial arrangement $(0.109,0.209,0.309$, and $0.409 \%$ aP and 0 or 5 ppm of ractopamine), with eight treatments, seven replicates, and two gilts per experimental unit. There were no interactions between aP levels and ractopamine. The levels of available phosphorus influenced both daily weight gain and daily phosphorus intake, which increased linearly. Feed conversion improved in a quadratic way up to the estimated level of $0.330 \%$ aP maximum response. Daily weight gain increased and feed conversion improved by adding ractopamine to the diets. Serum alkaline phosphatase activity decreased linearly by increasing the levels of available phosphorus. Bone strength, ash, calcium, and phosphorus contents in the bones also increased quadratically with maximum responses at $0.320,0.270,0.277$, and $0.295 \%$ aP respectively. The available phosphorus level of $0.330 \%$, corresponding to a daily intake of $8.67 \mathrm{~g}$ of aP is suitable for 94 to $125 \mathrm{~kg}$ gilts selected for meat deposition fed diets with or without ractopamine.

Key Words: beta agonist, carcass, ideal protein, minerals, performance

\section{Introduction}

Phosphorus is directly involved in essential metabolic functions in the animal organism. As a structural component of nucleic acids and phospholipids, it is essential for growth and cell differentiation, and contributes to the integrity and fluidity of cell membranes. Associated with other elements, phosphorus is important for maintaining osmotic pressure and acid-basic balance; it is one of the most important minerals for the formation and mineralization of the bone organic matrix.

As phosphorus is implicated in different vital metabolic functions, it is necessary to provide adequate levels of this mineral in the diets, not only to meet its requirement for optimum performance. In addition to fast and efficient growth, phosphorus is necessary to the proper development of bones, teeth and to enhance enzyme activities.

In addition to correcting mineral supplementation to maximize pigs performance, additives have been used in practical diets not only to improve performance but also carcass traits. Ractopamine has been widely used in the final stage of the finishing phase to increase weight gain and improve feed conversion with concomitant improvements in carcass quality. Ractopamine acts as a division agent, redirecting nutrients from the lipid synthesis to muscle deposition (Moody et al., 2000).

For the production of larger amounts of lean tissue, more nutrients participating in the protein metabolism become necessary. Phosphorus directly participates in protein synthesis. Thus, it is possible that pigs consuming diets supplemented with ractopamine have their needs for available phosphorus increased.

Given the above, there is a need to evaluate the effects of available phosphorus levels in diets with or without ractopamine on performance, carcass traits, bone, and blood parameters of 94 to $125 \mathrm{~kg}$ gilts with high genetic potential for meat deposition

\section{Material and Methods}

The experiment was conducted in conducted in Fazenda Experimental Vale do Piranga of the state-owned Empresa de Pesquisa Agropecuária de Minas Gerais (EPAMIG), Oratórios - MG, from November, 2008 to January, 2009. 
One hundred and twelve gilts genetically selected for meat deposition with initial weight of $94.0 \pm 2.28 \mathrm{~kg}$ were used. Gilts were allotted in a completely randomized block design, in a $4 \times 2$ factorial arrangement $(0.109,0.209$, 0.309 , and $0.409 \%$ aP and 0 or $5 \mathrm{ppm}$ of ractopamine), with eight treatments, seven replicates, and two gilts per experimental unit. Initial body weight was used as criterion in the blocks formation.

Treatments consisted of a basal diet with no phosphorus supplementation, containing $0.109 \%$ available phosphorus (aP) and three other experimental diets, obtained through the inclusion of dicalcium phosphate to the basal diet in place of inert and limestone.

Experimental diets (Table 1) were formulated in order to meet the nutritional needs recommended by Rostagno et al. (2005), except for available phosphorus. Diets containing ractopamine were identical to those not supplemented and were prepared changing $0.025 \%$ inert by a commercial product.

Pigs were housed in pens equipped with semi-automatic feeders and drinkers, located in a concrete floor facility, and covered with asbestos tiles. Pigs were fed ad libitum and water was provided throughout the experimental period.

At the end of the experiment all pigs were fasted for 12 hours, followed by 1 hour feeding ad libitum, thereafter they were fasted again for 4 hours and had no access to water during this period. Blood sampling was done immediately by puncturing the orbital venous sinus.

Blood samples were kept at rest for 1 hour at room temperature for clotting and clot retraction, and then centrifuged at $3500 \mathrm{rpm}$ for 10 minutes for separation of serum, which was stored in freezer at $-5{ }^{\circ} \mathrm{C}$. Serum alkaline phosphatase activity analysis was performed in Laboratory of Biochemistry - UFV, according to the technique described by Furtado (1991).

Following another period of 12 hours fasting, pigs were weighed and sent to a commercial slaughterhouse, where they were stunned and exsanguinated, according to the Brazilian rules for humane slaughter. Carcasses were individually evaluated using a typifying pistol introduced at the last rib position through the backfat and longissimus dorsi. Backfat thickness, hot carcass weight, meat

Table 1 - Calculated and nutritional composition of the experimental diets

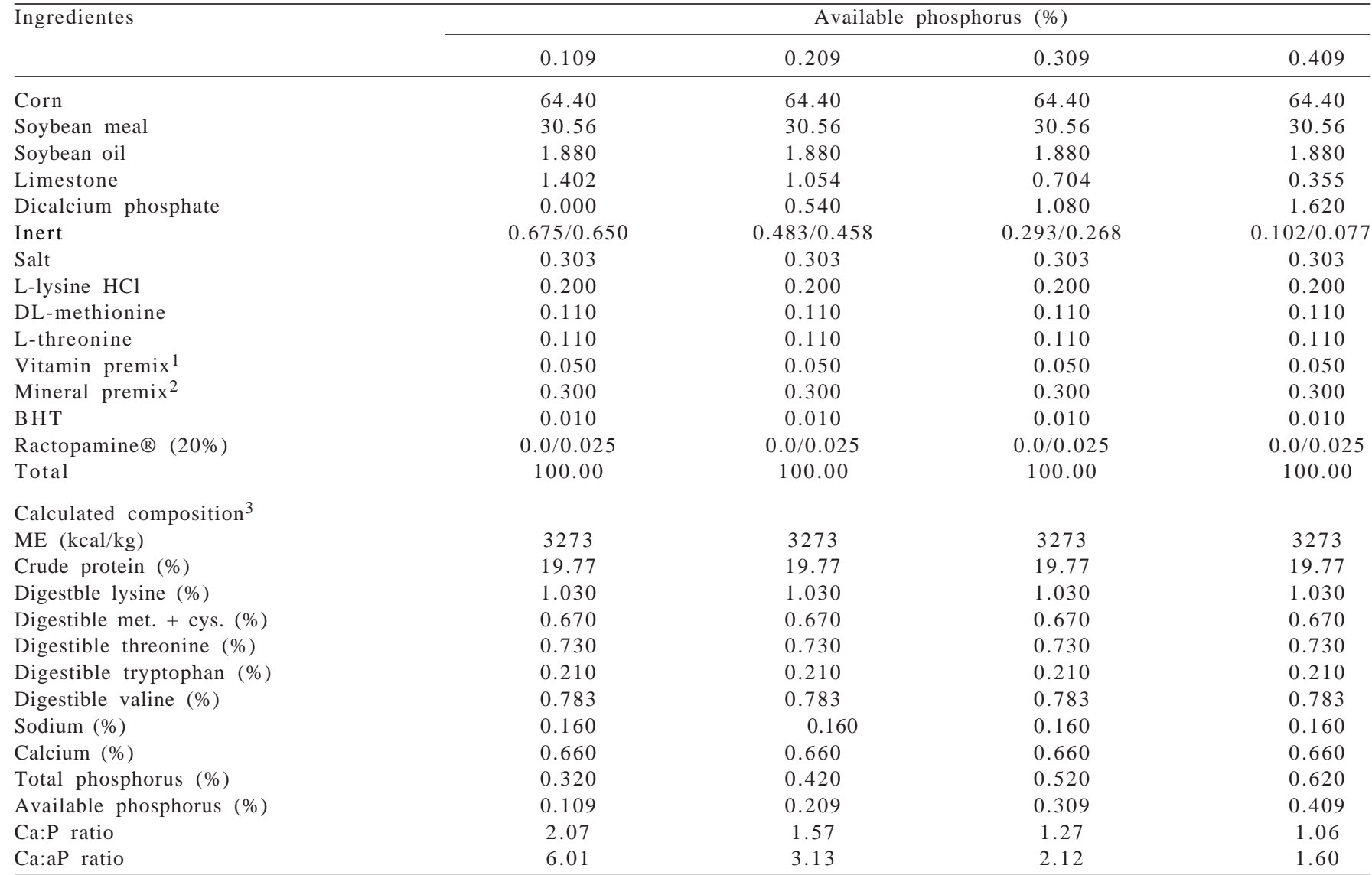

ME - metabolizable energy; met.+cys. - methionine + cystine.

${ }^{1}$ Content per kg of product: vitamin A - 1,225,000 IU; vitamin $\mathrm{D}_{3}-315,000 \mathrm{IU}$; vitamin E - 1,400 mg; vitamin K3 - 700 mg; vitamin B12 - 6,825 mg; selenium - 105 mg

${ }^{2}$ Content per kg of product: calcium - $98.8 \mathrm{mg}$; cobalt - $185 \mathrm{mg}$; copper - $15.75 \mathrm{mg}$; iron - $26.25 \mathrm{mg}$; iodine - $1.47 \mathrm{mg}$; manganese - $41.85 \mathrm{mg}$; zinc - $77.99 \mathrm{mg}$.

${ }^{3}$ According to Rostagno et al. (2005). 
percentage and kilograms of meat in the carcass were obtained considering each pig a replicate.

The metatarsals were used for determinations of bone strength, calcium, phosphorus and ash concentrations. Bones were oven-dried $\left(65^{\circ} \mathrm{C}, 72\right.$ hours) and then subjected to breakage by bending using the apparatus Instron Corporation IX Materials Testing System, adapted with support for bones in Laboratório de Materiais de Construção do Departamento de Engenharia Civil - UFV as described by Gomes et al. (1989).

For calcium, phosphorus, and ash analysis, bones were defatted in Soxhlet extractor, oven-dried $\left(65^{\circ} \mathrm{C}, 24\right.$ hours) and then crushed using a ball-type mill. Samples were then burned in an oven at $600{ }^{\circ} \mathrm{C}$ for determination of ash and, subsequently, the levels of calcium and phosphorus content in the sample were analyzed.

Performance, blood and bone parameters were subjected to analysis of variance using the softwear SAEG (System for Genetic Analysis and Statistics, version 9.1). The requirement of phosphorus was obtained based on the results, using regression models (linear or quadratic).

\section{Results and Discussion}

There was no interaction ( $\mathrm{P}>0.05)$ between the levels of available phosphorus and ractopamine on any of the parameters evaluated (Table 2). There was no effect $(\mathrm{P}>0.05)$ of available phosphorus on daily feed intake. These results are consistent with those obtained by Hastad et al. (2004) and Arouca et al. (2010), who also found no variation in the values of voluntary feed intake of finishing pigs due to the levels of available phosphorus in the diet.

Considering the results obtained by Moutinho (2008), Arouca et al. (2009) and Saraiva et al. (2009), who consistently found significant variation in voluntary feed intake of pigs in the initial and growing phases, according to the dietary available phosphorus, one can infer that finishing pigs seem to be less sensitive to the concentration of this mineral in the diet as they did not respond similarly to pigs in the growing phase, i.e., significantly altering feed intake according to the dietary available phosphorus levels.

The concentration of available phosphorus in the diet influenced $(\mathrm{P}<0.05)$ the available phosphorus intake, which increased linearly according to the equation $\hat{Y}=0.0101966$ $+26.2928 \mathrm{X}\left(\mathrm{r}^{2}=0.88\right)$. As there was no significant variation in feed intake of pigs among treatments, the observed linear increase in the consumption of available phosphorus is directly related to its concentration in the diet.

There was linear effect $(\mathrm{P}<0.05)$ of available phosphorus on daily weight gain according to the equation $\hat{Y}=0.7755$ $+0.30609 \mathrm{X}\left(\mathrm{r}^{2}=0.76\right)$. Significant change on daily weight gain of pigs from 95 to $120 \mathrm{~kg}$, as a consequence of the available phosphorus concentration in the diet was also observed by Arouca (2008), who obtained the greatest response at $0.210 \%$ available phosphorus.

On the other hand, Hastad et al. (2004), in a study with gilts from 88 to $109 \mathrm{~kg}$ found no effect of available phosphorus levels on the growth rate of pigs.

The inconsistency of results among studies may be related, among other factors, to the difference in the genetics of pigs concerning the potential for meat deposition and the level of calcium used in the experimental diets.

According to Liu et al. (2005), the mineral requirements of pigs may vary depending on the genetic potential for lean gain. As pigs with high potential for lean gain have higher amounts of bone and lean tissues, this may explain the increased demand for available phosphorus, since phosphorus is involved in the energy metabolism, synthesis of nucleic acids and structure of cell membranes.

Regarding the level of calcium, Reinhart \& Mahan (1986), in a study with finishing pigs observed a reduction in weight gain from the level of calcium in which the Ca:P ratios was above 1.3:1. This result is consistent with the report of Liu et al. (2000), who found that high Ca:P ratios reduce phosphorus absorption, impairing animal performance.

The available phosphorus levels influenced $(\mathrm{P}<0.05)$ pigs feed conversion, which improved quadratically up to $0.330 \%$ maximum response, corresponding to a daily intake

Table 2 - Performance of gilts according to the levels of available phosphorus and ractopamine in the diets

\begin{tabular}{|c|c|c|c|c|c|c|c|}
\hline \multirow[t]{2}{*}{ Item } & \multicolumn{4}{|c|}{ Available phossphorus (\%) } & \multicolumn{2}{|c|}{ Ractopamine (ppm) } & \multirow[t]{2}{*}{ CV (\%) } \\
\hline & 0.119 & 0.219 & 0.319 & 0.419 & 0 & 5 & \\
\hline Initial weight (kg) & 93.79 & 93.60 & 93.71 & 93.84 & 93.69 & 93.78 & 2.33 \\
\hline Feed intake (kg/day) & 2.70 & 2.66 & 2.63 & 2.68 & 2.73 & 2.61 & 9.33 \\
\hline aP intake (g/day) ${ }^{1}$ & 2.96 & 5.58 & 8.13 & 10.98 & 7.10 & 6.73 & 10.20 \\
\hline Weight gain $(\mathrm{kg} / \text { day })^{1}$ & 0.79 & 0.86 & 0.89 & 0.88 & $0.81 \mathrm{~b}$ & $0.91 \mathrm{a}$ & 11.54 \\
\hline Feed conversion ${ }^{2}$ & 3.46 & 3.14 & 3.00 & 3.06 & $3.43 \mathrm{~b}$ & $2.90 \mathrm{a}$ & 10.55 \\
\hline
\end{tabular}

Means followed by the same letter in row differ by the F test $(\mathrm{P}<0.05)$. CV - coefficient of variation.

${ }^{1}$ Linear effect $(\mathrm{P}<0.05)$.

${ }^{2}$ Quadratic effect $(\mathrm{P}<0.05)$. 
of $8.67 \mathrm{~g}$ of available phosphorus (Figure 1). However, the level of available phosphorus that provided the greatest feed conversion result in this study is higher than the level verified by Arouca (2008), who, working with barrows from 95 to $120 \mathrm{~kg}$ verified that feed conversion improved with increasing the available phosphorus concentration in the diet up to the level of $0.200 \%$.

The level of phosphorus that resulted in the greatest feed conversion result in our study corresponds to a Ca:Pd ratio of 1.98:1. This value is consistent with that of 1.95:1 recommended by Rostagno et al. (2005), confirming that calcium level in the experimental diet can influence the level of phosphorus. However, the Ca:P ratio of 1.98:1 verified in this study is below the ratio of 3:1 established by the NRC (1998). Thus, based on our results of feed conversion and those of Arouca (2008) it can be inferred that the level of $0.15 \%$ available phosphorus recommended by the NRC (1998) may not meet the nutritional requirements of pigs with high potential for lean gain in late finishing.

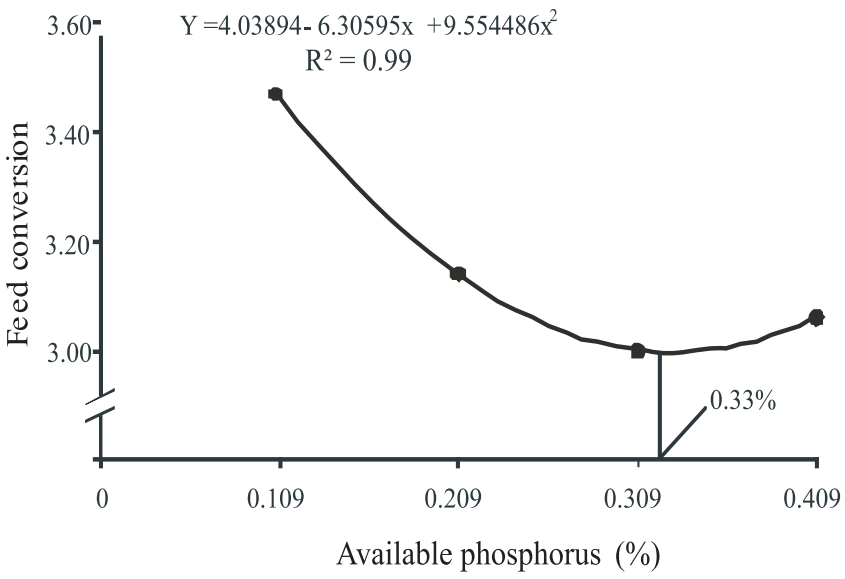

Figure 1 - Dietary available phosphorus levels effect in the feed conversion of 94 to $125 \mathrm{~kg}$ gilts.
The improvement in feed conversion associated with an increase in daily weight gain is an indication that there may have been a variation in the composition of gain with an increase in the percentage of protein and reduction in fat deposition.

Ractopamine influenced $(\mathrm{P}<0.05)$ pigs performance, resulting in $11 \%$ increase in daily weight gain and $15.45 \%$ improvement in feed conversion, i.e., there was an approximate $3.5 \mathrm{~kg}$ increase in the final body weight of pigs fed diets supplemented with ractopamine compared with those fed non-supplemented diets, corresponding to a $2.8 \%$ increase in the final weight of pigs. The improvement in these variables of performance may be linked to possible positive effects of ractopamine in body protein accretion.

Schinckel et al. (2003) and Marinho et al. (2007) reported that the best efficiency of nutrient utilization by pigs fed diets supplemented with ractopamine is due to its action in blocking lipogenesis and stimulation of protein deposition.

There was no effect $(\mathrm{P}>0.05)$ of available phosphorus levels on carcass traits of pigs (Table 3 ). Similar results were found by Arouca (2008), who, working with late finishing barrows also found no variation in carcass traits of animals based on the levels of available phosphorus in the diet.

Likewise, there was no effect $(\mathrm{P}>0.05)$ of ractopamine supplementation in the carcass traits assessed despite its positive effects observed in the pigs performance. Although not significant, there was an improvement of about 2.0\% in hot carcass weight of pigs fed diets with ractopamine.

Data of backfat thickness and meat amount in the carcasses of pigs obtained irrespective to the available phosphorus levels or ractopamine inclusion are not consistent with the results of performance, for which it improvements in daily gain and feed conversion were verified. This fact would indicate that the method used in

Table 3 - Carcass traits, bone, and blood parameters of gilts according to the levels of available phosphorus and ractopamine in the diets

\begin{tabular}{|c|c|c|c|c|c|c|c|}
\hline \multirow[t]{2}{*}{ Item } & \multicolumn{4}{|c|}{ Available phosphorus (\%) } & \multicolumn{2}{|c|}{ Ractopamine (ppm) } & \multirow[t]{2}{*}{ CV (\%) } \\
\hline & 0.109 & 0.209 & 0.309 & 0.409 & 0 & 5 & \\
\hline Hot carcass weight (kg) & 84.93 & 85.43 & 84.98 & 86.79 & 84.75 & 86.27 & 5.85 \\
\hline Backfat thickness (mm) & 13.43 & 13.54 & 13.14 & 13.69 & 13.68 & 13.31 & 21.43 \\
\hline Lean meat (\%) & 56.63 & 57.16 & 57.17 & 57.20 & 56.80 & 56.90 & 3.97 \\
\hline Lean meat (kg) & 48.70 & 48.85 & 48.55 & 49.96 & 48.46 & 49.55 & 7.93 \\
\hline SAFA - final $(\mathrm{U} / \mathrm{L})^{1}$ & 140.96 & 126.39 & 118.63 & 116.46 & 129.94 & 121.44 & 27.77 \\
\hline Bone strength $(\mathrm{N} / \mathrm{m})^{2}$ & 42.14 & 46.04 & 49.95 & 45.78 & 45.22 & 46.76 & 18.34 \\
\hline Bone phosphorus $(\%)^{2}$ & 8.39 & 8.94 & 9.02 & 8.81 & 8.68 & 8.88 & 6.50 \\
\hline Bone calcium $(\%)^{3}$ & 19.78 & 21.01 & 20.66 & 20.35 & 20.25 & 20.65 & 7.59 \\
\hline Bone ash $(\%)^{3}$ & 54.26 & 54.65 & 54.91 & 54.35 & 54.78 & 54.29 & 1.61 \\
\hline
\end{tabular}

CV - coefficient of variation; SAFA - serum alkaline phosphatase activity.

${ }^{1}$ Linear effect $(\mathrm{P}<0.01)$.

${ }^{2}$ Quadratic effect $(\mathrm{P}<0.01)$.

${ }^{3}$ Quadratic effect $(\mathrm{P}<0.05)$. 
the carcasses analysis was not sensitive enough to detect differences in carcass composition of pigs.

The levels of available phosphorus influenced $(\mathrm{P}<0.01)$ serum alkaline phosphatase activity decreasing linearly according to the equation $\hat{Y}=147.084-82.3152 X\left(r^{2}=0.89\right)$. This result corroborates the report of Koch \& Mahan (1986), where serum phosphatase is a parameter recommended for piglets because of the high rates of bone growth.

Bone strength was influenced $(\mathrm{P}<0.01)$ by the concentration of available phosphorus in the diets increasing quadratically up to $0.320 \%$ maximum response, corresponding to a daily intake of $8.42 \mathrm{~g}$ available phosphorus (Figure 2).

On the other hand, Arouca (2008) and Saraiva et al. (2009), in studies with pigs from 95 to $120 \mathrm{~kg}$ and from 30 to $60 \mathrm{~kg}$, respectively, found linear increase in bone strength by increasing the dietary levels of available phosphorus. The differences observed in the types of responses of bone strength between studies can be associated with the kinds of bone used, along with factors such as bone length, type of apparatus used for measurements, physical properties of the bone or its position in the equipment (Crenshaw et al., 1981), and the distance between the bases that hold the bone during the breakage.

The levels of available phosphorus influenced the percentage of phosphorus $(\mathrm{P}<0.01)$, calcium $(\mathrm{P}<0.05)$ and ash $(\mathrm{P}<0.05)$, which increased quadratically according to the equations $\hat{Y}=7.3996+11.2065 X-18.9622 X^{2}\left(r^{2}=0.99\right)$, $\widehat{Y}=17.9811+21.425 X-38.6522 X^{2}\left(r^{2}=0.84\right), \hat{Y}=53.1069+$ 12.8409X $-23.7064 \mathrm{X}^{2}\left(\mathrm{r}^{2}=0.91\right)$, up to the estimated levels of $0.300,0.280$ and $0.270 \%$ of available phosphorus, respectively.

The quadratic responses of bone parameters observed in this study confirms the report of Reinhart \& Mahan (1986), that both high and low phosphorus level in the

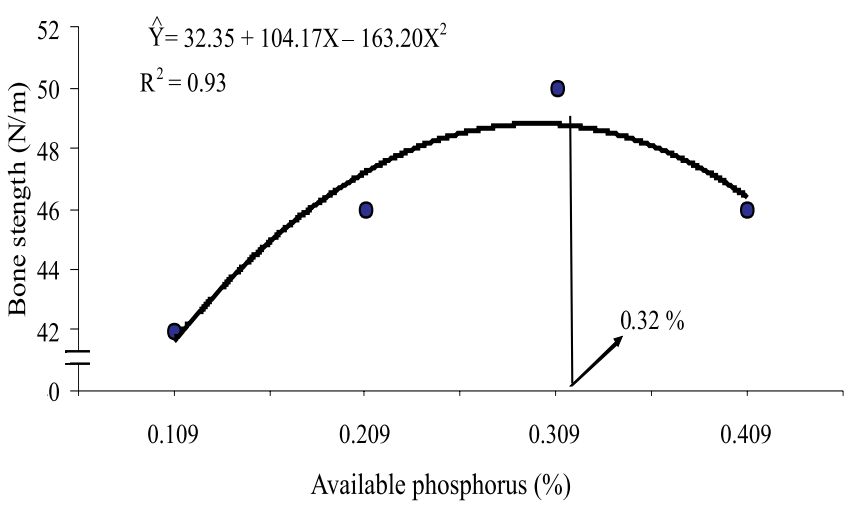

Figure 2 - Dietary available phosphorus levels effect in the bone strength of 94 to $125 \mathrm{~kg}$ gilts. diet may damage bone mineralization due to an improper Ca:P ratio.

According to Reinhart \& Mahan (1986), high levels of phosphorus in the diet may compromise the bone parameters of pigs, which is consistent with the results observed in this study, since the animals consuming the diet with the highest level of phosphorus had impaired bone strength and lower levels of ash, phosphorus, and calcium in the bones.

In a study with available phosphorus levels varying from 0.106 to $0.493 \%$ for 15 to $30 \mathrm{~kg}$ pigs, Moutinho (2008) found that phosphorus concentration in the diet influenced the amount of calcium and phosphorus in the bones, which increased quadratically with the increase in the levels of dietary available phosphorus up to the level of $0.369 \%$ maximum response.

The different results observed in the levels of ash between the studies may be due to the type of bones used in the assessment of this parameter; according to Cromwell et al. (1970) the nasal turbinate bones are more sensitive to variation in the level of phosphorus in the diet.

The calcium, phosphorus, and ash concentrations in bones obtained in this study do not confirm those of Partanen et al. (2010), who verified that the level of phosphorus that maximizes bone mineralization is greater than that required for increased bone strength. Therefore, practical diets for pigs with high potential for lean meat deposition may contain enough phosphorus to maximize bone strength, which will also ensure enough phosphorus for fast-growing pigs.

\section{Conclusions}

The recommended available phosphorus level in diets for 94 to $125 \mathrm{~kg}$ gilts with high potential for meat deposition, regardless ractopamine supplementation, is $0.330 \%$, corresponding to a daily intake of $8.67 \mathrm{~g}$.

\section{Acknowledgments}

Financial support was provided by FAPEMIG (Fundação de Amparo à Pesquisa de Minas Gerais - Brazil) and the Instituto Nacional de Ciência e Tecnologia de Ciência Animal-INCT-CA.

\section{References}

AROUCA, C.L.C. Exigência de fósforo disponível para suínos selecionados geneticamente para deposição de carne em diferentes fases de crescimento, dos 15 aos 120 kg. 2008 81f. Dissertação (Doutorado em Nutrição Animal) - Universidade Federal de Minas Gerais, Belo Horizonte, MG. 
AROUCA, C.L.C.; FONTES, D.O.; SILVA, F.C.O. et al. Exigência de fósforo disponível para suínos machos castrados selecionados para deposição de carne magra, dos 30 aos $60 \mathrm{~kg}$. Arquivo Brasileiro de Medicina Veterinária e Zootecnia, v.61, n.5, p.1094-1103, 2009.

AROUCA, C.L.C.; FONTES, D.O.; SILVA, F.C.O. et al. Níveis de fósforo disponível para suínos machos castrados dos 60 aos 95 kg. Revista Brasileira de Zootecnia, v.39, n.12, p.2691-2698, 2010.

CRENSHAW, T.D.; PEO, E.R.; LEWIS, A.J. et al. Bone strength as a trait for assessing mineralization in swine: a critical review of techniques involved. Journal of Animal Science, v.53, p.827, 1981.

GOMES, P.C.; ROSTAGNO, H.S.; PEREIRA, J.A.A. et al. Exigência de fósforo total e disponível para suínos na fase de crescimento. Revista Brasileira de Zootecnia, v.18, n.3, p.232-239, 1989.

HASTAD, C.W.; DRITZ, S.S.; TOKACH, M.D. et al. Phosphorus requirements of growing-finishing pigs reared in a commercial environment. Journal of Animal Science. v.82, p.2945-2952, 2004.

KOCH, M.E.; MAHAN. D.C. Biological chacacteristics for assessing low phosphorus intake in finishing swines. Journal of Animal Science, v.62, p.163-172, 1986.

LIU, J.; BOLLINGER, D.W.; LEDOUX, D.R. et al. Effects of dietary calcium:phosphorus ratios on apparent absorption of calcium and phosphorus in small intestine, cecum and colon of pigs. Journal of Animal Science, v.78, p.106-109, 2000.

MARINHO, P.C.; FONTES, D.O.; SILVA, F.C.O. et al. Efeito dos níveis de lisina digestível e da ractopamina sobre o desempenho e as características de carcaça de suínos machos castrados em terminação. Revista Brasileira de Zootecnia, v.36, p.1791-1798, 2007.

MOODY, D.E.; HANCOCK, D.L; ANDERSON, D.B Phenethanolamine repartitioning agents. In: MELLO, J.P.F.D (Ed.). Farm animal metabolism and nutrition. New York: CAB, 2000. p.65-95.

MOUTINHO, J. Biodisponibilidade de fósforo em fosfatos e níveis de fósforo disponível para suínos na fase inicial. 2008. 52f. Dissertação (Mestrado em Zootecnia) - Universidade Federal de Viçosa, Viçosa, MG.

PARTANEN, K.; SILJANDER-RASI, H.; KARHAPÄÄ, M. et al. Responses of growing pigs to different levels of dietary phosphorus - Performance, bone characteristics, and solubility of faecal phosphorus. Livestock Science, v.134, p.109-112, 2010.

REINHART, G.A.; MAHAN, D.C. Effect of various calcium:phosphorus ratios at low and high dietary phosphorus for starter, grower and finishing swine. Journal of Animal Science, v.63, p.457-466, 1986.

ROSTAGNO, H.S.; ALBINO, L.F.T.; DONZELE, J.L. et al. Tabelas brasileiras para aves e suínos; composição de alimentos e exigências nutricionais. 2.ed. Viçosa, MG: Imprensa Universitária, 2005. 186p.

SARAIVA, A.; DONZELE, J.L.; OLIVEIRA, R.F.M. et al. Níveis de fósforo disponível em rações para suínos de alto potencial genético para deposição de carne dos 30 aos $60 \mathrm{~kg}$. Revista Brasileira de Zootecnia, v.38, n.7, p.1279-1285, 2009.

SCHINCKEL, A.P.; RICHERT, B.T.; HERR, C.T. et al. Development of a model to describe the compositional growth and dietary lysine requirements of pig fed ractopamine. Journal of Animal Science, v.81, p.1106-1119, 2003. 